\title{
Aotearoa New Zealand Social Work rebooted: Open access and the intellectual commons
}

This issue of the journal marks a new stage in the continuing journey of Aotearoa New Zealand Social Work: this is our first open access issue and all journal content will now be freely available to anyone in the world from our new journal website (http://anzswjournal.nz). By taking this step we are contributing to a worldwide open access movement and to the foundation of an intellectual commons where the fruits of academic labour are available to all. Our open access platform will also extend the international readership of the journal, increasing the likelihood that authors will have their work read and cited. The decision to move to open access is linked to several other recent developments not least of which was the formation of an editorial collective to take over the management of the journal from our outgoing editors Kieran O'Donoghue and Mary Nash. We acknowledge the work of Mary and Kieran who were the last in a long line of New Zealand social work academics willingly giving their time and attention to sustaining the journal. Editing an academic journal is an important task, but it is also an onerous one. Sharing the responsibility with a larger group of colleagues who are happy to work in a collective way makes a lot of sense. Such an arrangement also has the advantage of building editorial capacity as more experienced members support and mentor colleagues who are newer to the craft.

The core of our editorial collective had already been working together as an academic blogging collective called Reimagining Social Work (RSW) (http://www.reimaginingsocialwork.nz/ about/). These core members were joined by the existing editors of Te Komako (Shayne Walker and Anaru Eketone from the University of Otago), and by Jane Maidment and Yvonne Crichton-Hill from the University of Canterbury. The editorial collective is now ten strong and members will take turns to act as duty editors for forthcoming journal issues, with this issue edited by Neil Ballantyne (the Open Polytechnic of New Zealand) and Simon Lowe (University of Waikato). The editorial collective has established an editorial advisory board of national and international academics with expertise in scholarly publication (https:/ /anzswjournal.nz/ anzsw/about/editorialPolicies). Over time this will help to build a strong international presence for the journal without losing our distinctive Aotearoa flavour (a flavour that, as you will see, permeates the current issue).

The transition to an open access journal offered us the opportunity to modernise the journal's look and feel and we hope our readers enjoy our new brighter and bolder style. The journal continues to be owned and published by the Aotearoa New Zealand Association of Social Workers (ANZASW), and is being hosted on an installation of the Open Journal System (OJS) software as part of the University of Otago's OUR journal service. We are indebted to the help and assistance that the University of Otago librarians and IT staff have provided in making our transition to open access as smooth and painless as possible. The new system hosts the journal content, but it will also manage the article submission and peer review process. Readers and authors can now subscribe and register online to receive journal updates and to allow authors to submit an article for review. Finally, we have adopted a Creative Commons license for all journal articles from this issue onwards. This means that readers of the journal will not
AOTEAROA

NEW ZEALAND SOCIAL WORK 28(1),1-4. 
only be able to access journal content freely, they can also copy, distribute and reuse journal materials so long as they attribute the article author and recognise the rights of the ANZASW.

All of these new journal developments are exciting, but a journal is nothing without the efforts of its authors and we are delighted to introduce a compelling collection of articles that give a snapshot of social work in Aotearoa today. The issue opens with an article by Hyslop entitled Where to social work in a brave new neoliberal Aotearoa? The fifth National Government of New Zealand are in their third consecutive term of office and have been in power since 2008. This government, under the leadership of Prime Minister Joh Key, likes to describe itself as politically pragmatic in nature, but one doesn't have to look too far to detect evidence of its true neoliberal colours. In previous terms of office it has introduced prison privatisation to the corrections service and charter schools to education. During its current term government has turned its attention to social service reforms (The New Zealand Productivity Commission, 2015) and a radical review and restructure of child protective services (Modernising Child Youth and Family Expert Panel, 2016).

Hyslop's article explores the ideological underpinnings of the government reforms paying particular attention to a proposal for the introduction of a predictive risk modelling tool that would, if implemented, run a computer algorithm on information held on government databases about beneficiary families to produce a child maltreatment risk score. The title of Hyslop's article contains, of course, a reference to Aldous Huxley's dystopian novel on the dark side of scientific futurism. Hyslop responds to the government's hi-tech proposal by highlighting its historical resonance with a much older narrative about the need to control a dangerous underclass, and the imposition of a moral order that locates risk and dangerousness inside individuals whilst remaining oblivious to the material risks associated with gross inequality and the economic privations of far too many New Zealand families. Hyslop throws down the gauntlet to all social work practitioners asking them to consider carefully their role in the profession and the way in which this may be shaped by a neoliberal turn to technology in child protection policy.

There can be little doubt that one of the drivers of policy making in the child protection domain is the intense media interest that inevitably follows failures in the child protection system. System failures often lead journalists to point the finger of blame, and that finger frequently points at social workers. Small wonder then that social workers might have concerns about how they are perceived by the public. But how are they perceived? and how do social workers believe the public perceive them? In a previous article, Staniforth, Fouché \& Beddoe (2014) explored the first of these questions and found the New Zealand public to be generally sympathetic to, and relatively well informed about, social work and social workers. The article in the present issue - by Staniforth, Deane and Beddoe - compares the earlier findings on public perception of social workers, with new findings on how social workers themselves believe they are perceived by the public. This article has important implications for the education of beginning social workers and for awareness raising amongst practising social workers. One reassuring finding is that, in spite of their largely negative views on how the public perceive them, the overwhelming majority (96\%) of their sample remain stubbornly proud to be social workers.

Social workers do not work in isolation from other professionals and in all contemporary fields of practice, especially in the health sector, multidisciplinary teamwork is the order of the day. We have known for some time that, when it works well, multidisciplinary practice has enormous benefits for the users of social work services; but we also know 
that enabling different professional groupings to work together can be fraught: professional socialisation, different practice philosophies and differential status can all work against effective multidisciplinary practice. In her case study of hospitalbased multidisciplinary team work, Giles explores health social workers' views of multidisciplinary teams. The study confirms the clear benefits to be derived from effective multidisciplinary team work, but also highlights the ways in which a predominant medical discourse with an undue emphasis on risk, and a focus on the patient as a 'site of disease', can sometimes overshadow more holistic, patient-centred perspectives.

Qualitative methodologies feature strongly in social work research and one of the great traditions of this approach is in giving voice to the users of social work services, especially those who are hard to reach or on the margins of society. The article by Thorburn, using data from interviews with underage sex workers, is a good example of this tradition. The study explores the views of underage sex workers on their work and its relationship with earlier childhood and adolescent experiences. The findings tell a story of abuse, manipulation and powerlessness and offer disturbing illustrations of the grave risks from male violence - from clients and partners - that appear to be an accepted part of underage sex work in New Zealand.

One of the unique characteristics of social work in New Zealand is the bicultural arrangements that flow from the Treaty of Waitangi (the founding constitutional document between the British colonial government and Māori tribal leaders). The term bicultural is used to refer to a number of very different practical and organisational arrangements that attempt to recognise the distinctive status of Mãori as the indigenous people of Aotearoa New Zealand. For New Zealand social workers, the vital importance of the Treaty, and historical legacy of colonisation, is reinforced daily in the form of the gross over-representation of
Māori in the care, correctional and health systems, and in various negative social indicators from incarceration to poverty rates. It is therefore not surprising that the ANZASW (the professional association of social workers in New Zealand) has attempted to grapple with biculturalism within its own constitutional arrangements; yet this has not been without challenge. The article by Fraser and Briggs delves deeply into historical archive and surfaces with a real taonga (treasure) in the form of a historical account of some highly significant events in forging the professional association's bicultural constitution. Given that the association has just passed its fiftieth birthday, and that a new debate on the meaning of biculturalism for the ANZASW has emerged, this article is very timely indeed.

Whilst biculturalism refers to the distinctive place of Māori as the original tangata whenua (people of the land) of New Zealand, there is no doubt that New Zealand is also a nation of migrants, an increasingly multicultural nation, and - because of its geographical location as an island group in the southwestern Pacific Ocean - a Pacific nation. The next two articles explore different aspects of this positioning. The article by Adelowo, Smythe and Nakhid offers an Africentric narrative analysis of the stories of Black African women who had recently migrated to New Zealand. In place of the stereotypical view of impoverished, female African migrants fleeing failed African states to join husbands abroad what emerges from these stories is a view of the women as active agents in their own lives, weighing up the push and pull factors that influenced their motivation to migrate, and making positive choices to enhance their careers and the educational and economic opportunities for their families. Such narrative insights challenge assumed views on the experience and motivation of new migrants, and make essential reading for social workers working with migrant communities. 
In the last of our original articles Tofuaipangai and Camilleri offer an innovative analysis of social policy by contrasting the Western concept of obligation with its Tongan synonym of fatongia. The striking conceptual contrast and different cultural resonances of these two terms is used to offer a devastating critique of the way in which Western social policy has transformed the traditional obligation of the welfare state to support families into an oppressive and coercive obligation on individuals and families to meet the eligibility criteria of the state. The Tongan concept of fatongia, where mutual obligation is recognised as a positive gift that connects and binds people in networks of collectivity, is used as an alternative conceptual lens with which to think about progressive social policy.

Finally, we have a new section of the journal called Viewpoints. Viewpoints is a section where authors can submit shorter (max length 1,500 words) points of view, discussions and reflections on a clear and focused social work topic. The viewpoint presented by Martin (a social work student at the University of Otago) is a good example of the genre. Martin discusses ethical dilemmas in social work practice and confronts the distinction between the more abstract classroom discussion of ethics, and the ethical dilemmas that can emerge in practicum situations where unequal power relationships and other social pressures (such as the need to pass the practicum) can make ethical action more challenging.

We hope that you enjoy our first open access issue of the journal, and we invite you to subscribe to the website as readers and/or prospective authors. We also welcome any feedback you might have to offer on the new look journal, to do so just send an email to editors@anzasw.nz

\section{References}

Modernising Child Youth and Family Expert Panel. (2016). Expert panel final report: Investing in New Zealand's children and their families. Wellington, New Zealand: Ministry of Social Development. Retrieved from https://www.msd.govt.nz/documents/about-msd-andour-work/work-programmes/investing-in-children/ investing-in-children-report.pdf

New Zealand Productivity Commission. (2015). More effective social services. Wellington, New Zealand: Author. Retrieved from http://www.productivity.govt.nz/ sites/default/files/social-services-final-report-main.pdf

Staniforth, B., Fouché, C., \& Beddoe, E. (2014). Public perception of social work and social workers in New Zealand. Aotearoa New Zealand Social Work, 26(2/3), 48-60. 